\title{
Features of the protection of the intellectual property related to the military-industrial complex of Russia
}

\author{
Mikhail Kuznetsov ${ }^{1}$, Viktor Ponka ${ }^{1}$, and Ivan Chumachenko ${ }^{1, *}$ \\ 1Peoples' Friendship University of Russia (RUDN University), 117198, 6 Miklukho-Maklaya str., \\ Moscow, Russia
}

\begin{abstract}
An integral part of today's cross-border civil and trade relations is cooperation and trade in the military-industrial complex. One of the key problems for the countries selling production of the military-industrial complex is the protection of the intellectual property rights in the field of defence industry. Russia, being one of the biggest arms exporters in the world, has accumulated an interesting experience of legal regulation of this problem. This article focuses on aspects of intellectual property protection in the sphere of military-industrial complex.
\end{abstract}

\section{Introduction}

The scientific and technological progress plays an important role in existence and development of the contemporary society. The term of scientific and technological progress itself is directly related to innovations in all the spheres of the society.

The creation of the highly-developed legislative and regulatory framework that governs the protection of intellectual property was initiated in cause of the increasing a number of scientific discoveries in Russia and in cause of globalization processes, which was reflected in the establishment of the Eurasian Customs Union. (The Eurasian Customs Union (EACU) is a customs union which consists of all the member states of the Eurasian Economic Union). But on the other hand, the main factor that hinders the creation of the sustainable system of protection of intellectual property in Russia and in the CIS (The Commonwealth of Independent States) countries is traditional resistance to change and a relatively undeveloped intellectual property market as an economic category.

According to O. L. Kurochkina, weak capitalization of intellectual property in Russia is one of the key intellectual property issues, which, to a certain degree, contributes to its violation [7]. Moreover, the number of patents granted in the Russian Federation during the last years increased by only $10-15 \%$ and amounts to approximately 20,000 patents per year. The legal protection of intellectual activity achievements is necessary for their legal circulation in Russia and abroad. Even during the Soviet Union period, in 1980-1990s, more than 150,000 applications for inventions were submitted annually, and 3,000-4,000 inventions were patented abroad every year [7].

* Corresponding author: ivan26061989@mail.ru 
The intellectual property market is characterized by its fragmented structure and heterogeneity. This fact manifests itself in the limited and relatively static performance of some of its segments related to innovation, patented inventions, know-how, integrated schemes, plant varieties, industrial design markets [7].

Authors of this article think that in Russia the issues related to the intellectual property protection were raised only after the collapse of the USSR. As the military-industrial complex was not commercialized and mainly focused on the fulfilment of government orders, cash flows were not linked to the civil turnover; therefore, there were not one paid due attention to the protection of intellectual property.

Since the Russian Federation ranks 2nd in the market of export of arms and dual-use goods, the key issue for Russia, as an exporter of such products, is a specific need for the establishment of effective legal methods of protection of intellectual property for the military-industrial complex. However, according to A. D. Korchagin, the measures taken in the field of science, technology and innovation are ineffective. The main reasons for this situation are as follows:

- There is no government policy on legal protection and use of the results of scientific and technical activities and intellectual property objects;

- There is no federal executive body which is responsible for the sphere of innovation and for legal protection and use of research and development achievements in Russia;

- There are no clearly defined interests of the government regarding research and development results and intellectual property objects [6].

The authors believe that for quite a long period of time, the government had not paid much attention to this issue. This caused many disputes between the MIC (MIC stands Military industrial complex) manufacturers in Russia and abroad. And unlicensed production of military product samples, as well as dual-use goods, theft of patents on the newest inventions in the field of the military-industrial complex, and lack of control of their use, lack of regulatory framework in terms of protection of industrial property transferred abroad also contributed to these disputes. One of the most striking examples of the abovementioned problems is the unlicensed production of the world famous Kalashnikov assault rifle. Many researchers understand the licensed production abroad as a practice whereby one company allows and enables other companies to produce its products under the license in another country. Depending on terms and conditions of these agreements, a licensee may obtain some components, half-finished products, drawings, equipment, and even technical staff for the project. In the international practice this problem was identified as the Kalashnikov threat. In many countries Kalashnikov assault rifles are being produced illegally. Only 12 countries produce such rifles officially, while counting the illegal producers is impossible. The majority of foreign fakes are much worse in quality and discredit the work of Russian armorers. Almost at every exhibition Russian representatives have to make a complaint about foreign manufacturers who produce fake Soviet arms. In fact, a patent for the Kalashnikov assault rifle obtained in 1997 (world patent WO9905467 as of 4 February 1999) actually protects only certain design decisions embodied in machines series AK-74M (AK means "Kalashnikov assault rifle"), but does not protect earlier models, such as AK and AKM (AK and AK means different types of the modifications of Kalashnikov assault rifle). Consequently, most of the Kalashnikov assault rifle models can be produced without any license. This article is devoted to these issues and to ways to resolve them at national and transnational levels.

\section{Protecting the rights for the industrial property objects, guided to the international exhibitions}


Naturally, participation in international exhibitions of arms is important for every industrial enterprise and provides a lot of opportunities and benefits for the subsequent implementation of exhibited products into production and for the search for customers. However, the authors of this article points out not only the benefits that a manufacturer gains from participating in exhibitions, but also a number of risks for a military products manufacturer linked to a possible loss of intellectual property for these products or unauthorized copying of those industrial property objects.

The exhibited samples produced by the Russian manufacturers are not always patented at the moment of their first presentation or later. The authors believe that this is caused by the weak regulatory mechanism of legal protection for the industrial property samples displayed at exhibitions before filing a request to the National Patent Office. One of the main objectives of the exhibitions is the presentation of the samples of the new products, latest inventions and utility models. The inventors get the opportunity to promote their products, to perform marketing analysis and find prospects. At the same time, if the exhibited samples do not have proper legal protection through patenting, the invention disclosure creates real threat of its unauthorized use and copying, and may anticipate newness of the invention and thus may create additional difficulties with further patenting.

O. L. Kurochkina points out that according to international practice, this problem is being solved by the so-called "novelty grace period" for inventions, utility models and industrial samples and by exhibition priority for trademarks demonstrated at exhibitions.

The determination of the status of an exhibition is one of the key issues in the exhibition priority setting. However, the current legislation does not define the concept of "the official or the officially recognized international exhibition." Moreover, the legislation does not set the clear procedure for confirmation of the industrial property demonstration at the exhibition, which facilitates industrial espionage [7].

The authors also believe that another measure aimed at protecting intellectual property for samples exhibited abroad is the conclusion of an indemnity contract or an unilateral indemnity agreement which obliges the organizer of an exhibition to indemnify the inventor or the manufacturer of the military-industrial complex in case of negative consequences linked to a theft of inventions in the course of the demonstration of these inventions at the exhibition.

In addition to it, there are some other measures which can be taken to protect intellectual property rights for the industrial samples exhibited abroad. These are the socalled de facto protection measures, which will be elaborated below.

All the above-mentioned measures let the domestic military-industrial enterprises minimize the risks linked to loss of intellectual property for industrial samples at the early stage of their implementation.

\section{The de facto protection of intellectual property rights for the military-industrial complex samples supplied abroad: technical protection for industrial property objects}

Under this type of the protection, the authors determine the following methods: using the means of individualization for the military-industrial complex products and dual-use items delivered abroad, inclusion of points on commercial secrets into supply contracts for MIC production; attestations and guarantees that prove the supplier to be the original manufacturer of the products supplied; technical protection of industrial property objects.

In the military-industrial complex, one of the simplest and at the same time the most effective ways to protect intellectual property is to put the manufacturer individualization marks on the products. The Customers usually insist on a specific product name already at 
the stage of technical project approval. As a result, the use or the non-use of the trademark for the specific product is determined by the customer rather than by the manufacturer who is also the copyright holder at the same time. This makes it difficult to choose a designation for registration. According to the authors, this measure protects a buyer of the militaryindustrial complex products against the risks associated with purchase of products, which were made without the proper license or without the right to manufacture such products. This measure also protects the seller against the risks related to the possible transfer of the object of delivery to a third party for copying or to a potential theft of intellectual property.

In addition to it, one of the most effective measures aimed at limiting the usage of the product by a buyer and at preventing the risks of a seller linked to the subsequent loss or the theft of intellectual property is the inclusion in the contract the assurance or the guarantee from the buyer, as the end-user of the products supplied, not to resale or reproduce the goods.

As of today, this form of protection of industrial property objects is the most popular (also in the military-industrial complex) due to its efficiency, effectiveness and the possibility to apply it proactively. Among all the technical methods designed to protect the industrial property, the most common are programs that restrict the access to Internet resources for Internet pirates (persons who illegally download and distribute files that are potentially being stolen objects). The Russian legislation provides a legal definition for the information security. According to Art. 1300 of the Civil Code of the Russian Federation, which provides the protection of information, defines information on copyright law as any information that identifies a work, an author or another right holder or the information on the terms of using a work available on the original work or a copy of the work, is attached thereto or appears in connection with a broadcast or cable program or in connection with the bringing of the work to the notice of the general public, and also any figures and codes containing such information1. The following is prohibited in respect of a work: deleting or modifying information on copyright law without the author's or other right holder's consent; the playback/reproduction, distribution, importation for the purpose of distribution, public performance, broadcasting or cable transmission, bringing to the notice of the general public of a work in respect of which information on copyright law has been deleted or modified without the author's or other right holder's consent.

This is a special way of copyright protection against illegal copying and using copyright.

The above-mentioned information let us conclude that today technical and copyright protection is by far the most applicable and effective method of intellectual property right protection for three main reasons: (1) their effectiveness; (2) the possibility of their use at the transnational level without limitation, if their application does not violate any applicable laws of the local jurisdiction; (3) their better availability for the persons participating in the protection of intellectual property in comparison to other methods.

However, today we cannot say for sure that technical methods of protection of industrial property objects are fully understood. The society and the institution of copyright are developing, and, therefore, the ways of protection of industrial property objects, in general, and the methods of technical protection of industrial property rights, in particular, are developing as well. And today, in the era of globalization, these methods are used perfectly well.

\section{The question of the confidentiality regime under the TRIPS Agreement standards in relation to intellectual property}

Standards of the TRIPS Agreement (TRIPS Agreement) are established not only in respect of the intellectual property, but also with regard to the confidential information and control 
of unfair competition of the entering into the license agreements. The standards of confidential information regime are identified in Article 7 of the TRIPS Agreement [12]. It should be emphasized that the inclusion of rules on closed information in the text of a multilateral international agreement is, in fact, the first attempt which is aimed at ensuring of the protection of trade secrets at the international level. Such an attempt should be welcomed, although the emergence of the protection of confidential information among intellectual property rights, a phenomenon by no means unambiguous.

According to paragraph 1, Art. 39 TRIPS Agreement, member countries are obliged to take legal actions for the protection of classified information in the context of ensuring effective protection against unfair competition as provided in Art. 10. bis of Paris Convention [12]. Point. 1, Art. 39 of the TRIPS Agreement, in essence, adds an illustrative list of acts of unfair competition, stated in para. (3) Art. 10 of the Paris Convention, introducing activities related to the illegal receipt, distribution or use of information held as a trade secret 8 .

Persons and legal entities, who has the title on the information covered by these signs, within the meaning of Art. 1 pt. 2 of Art. 39 of the TRIPS Agreement are endowed with legally secured opportunity to prevent the relevant information under their control have been disclosed, obtained or used without the consent of the other party a manner contrary to honest commercial practices [12]. At the same time a manner contrary to honest commercial practices, is meant at least practices such, as breach of contract, loss of confidence or assistance undermine trust, including the acquisition of undisclosed information by third parties who obviously knew or showed negligence in respect of what ways were obtained information acquired by them.

\section{Registration of patents as a way of protection of intellectual property (military-industrial complex production), supplied abroad}

The legislation of the Russian Federation provides the concept of patent rights, as well as the procedure for the registration of patent rights. Article 1349 of the Civil Code of the Russian Federation specifies that the objects of patent rights are the results of intellectual activities in the area of science and technology that meet the requirements established by the Civil Code of the Russian Federation as applicable to inventions and utility models, and the results of intellectual activities in the area of artistic design that meet the requirements established by the present Code as applicable to industrial designs [1].

Registration and subsequent protection of rights of intellectual property abroad is provided in accordance with national, regional or international registration systems.

The Russian Federal Service for Intellectual Property is an authorized body for the registration of patents in the national and international system of registration of patents. The authorized body can act only on the basis of special federal laws and bilateral and multilateral agreements in the field of protection of intellectual property. Bilateral intergovernmental agreements between the Russian Federation and the Republic of Azerbaijan, Republic of Armenia, Belarus, Georgia, the Republic of Kazakhstan, Kyrgyz Republic, Uzbekistan, Ukraine provide that the patent attorneys of one state can do business directly with the patent office of another state, representing only the interests of the residents. Residents also have the right to deal directly with the patent office of another state. The system of bilateral relations substantially facilitates registration and protection of industrial property, registered in one state on the territory of another state.

The Russian Federation is a party of several international treaties that establish international systems of registration of rights for various kinds of intellectual property 
objects. These treaties include the Madrid Agreement Concerning the International Registration of Marks as of 04.14.1891 and the Protocol to it as of 28.06.1989 [4], the Patent Cooperation Treaty as of 19.06.1970 [9], the Hague Agreement Concerning the International Deposit of Industrial Designs as of 06.11.1925 [2], as well as the Lisbon Agreement for the Protection of Appellations of Origin and their International Registration as of 31.10.1958 [3].

\section{Jurisdictional (judicial) method of protection of intellectual property in the field military-industrial complex}

Alternative methods of disputes resolution in addition to the option of the resolving of the disputes in the state courts are reliable and fairly common way to ensure protection of intellectual property in the field of the military-industrial complex. In this regard, it should be noted that the key point of the Agreement on Trade-Related Aspects of Intellectual Property Rights (TRIPS agreement) is a requirement for States to allow the exercise of intellectual property rights. One of the most successful examples of the implementation of this requirement is the creation of Court of intellectual property and international trade in Thailand (the Intellectual Property and International Trade Court in Thailand). This court was established jointly by the Ministry of Justice and the Ministry of Commerce of Thailand under the TRIPS Agreement. This organ was set up in line with the overcoming of disagreements on Trade-Related Aspects of Intellectual Property Rights between the United States and the European Union on the one hand and Thailand on the other hand. In addition, it will be interesting to note the work of WIPO's Arbitration and Mediation Center. In addition to issues related to intellectual property, this authority has exclusive jurisdiction in matters of international trade. This Center is the only international organization that specializes in the resolving of disputes in the field of technologies, entertainment and other disputes in the sphere of intellectual property protection. Since its foundation, the Center also enacted arbitration for the resolution of the general contractual issues, financing transactions and employment contracts associated with the emergence, implementation, termination of copyrights.

In order to facilitate the settlement of intellectual property disputes, the WIPO Center of Arbitration and Mediation executes the following functions:

- Provides help for parties in resolving their disputes under the WIPO procedures in cases where they have not previously made a reservation to transfer of disputes to WIPO;

- Assisting in the choosing of mediators and arbitrators from the Center database containing more than 1,000 names of neutral experts, who have experience on the settlement of intellectual property disputes;

- Linking the parties and neutrals to ensure optimal communication and efficiency of proceedings;

- Organizing support services, including translation, interpretation and secretarial functions;

- Setting fees of neutral experts, after consultation with the parties and the arbitrators and decides the financial aspects of the proceedings;

- Providing free premises, if the proceedings taking place in Geneva, and take the necessary organizational measures for their rent, if it takes place elsewhere [14].

In general, we can note the leading role playing by the WIPO as an international organization in the development of international legal instruments to ensure the effective protection of copyrights, as well as in the establishment of effective mechanisms to implement the effective system of resolution of disputes in the area of copyrights protection. 
At the end of this section of the article the authors would like to note that the establishment of the Court for intellectual property rights in Russia as the one of the last trends relating to the improvement of the level of the intellectual property protection. Creation of a specialized court, which would be professionally and efficiently resolve all intellectual property disputes, is necessary to increase as the investment attractiveness of the Russian economy and the effectiveness of protection of intellectual property rights system. The resolve of such disputes requires the special knowledge's which should be obtained by the court judges.

The Court for intellectual property rights in Russia is empowered to settle following disputes:

1. Cases related to the disputing of the legal acts of federal enforcement authorities, concerning the rights and legitimate interests of the applicant in the field of legal protection of results of intellectual activity and means of individualization, including the field of patent rights and rights to breeding achievements; rights to topographies of integrated circuits, rights to trade secrets (know-how); the right to the means of individualization of legal entities, goods, works, services and businesses; right to use the results of intellectual activity in the same technology;

2. Disputes regarding the granting or termination of legal protection of results of intellectual activity and equated means of individualization of legal entities, goods, works, services and companies (with the exception of the copyright objects and related rights, topographies of integrated circuits);

The Plenum of the Supreme Arbitration Court in para. 7 of the Ordinance of October 8, 2012 N 60 extended the list of cases which should be settled by the Intellectual Property Court and added up the following types of cases:

1. Disputes about violations of intellectual property rights to the results of intellectual activity and equated means of individualization of legal entities, goods, works, services and businesses, on the right of prior use and subsequent use, as well as disputes arising from contracts on alienation of the exclusive right and license agreements to be consideration by courts of arbitration, if the parties to legal disputes are legal entities or individual entrepreneurs, and the corresponding dispute is related to business and other economic activities;

2. Disputes with the organizations engaged in copyright collective, considered by arbitration courts, regardless of whether acts such organization in the court on behalf of the holders (legal entities and individual entrepreneurs or citizens who are not individual entrepreneurs) or on its behalf.

The Court for intellectual property rights was founded under the following causes:

1. Increasing in the number of disputes relating to intellectual property rights;

2. In cause of need of the formation of a professional judiciary and greater involvement in the process of individuals with special knowledge in the field of intellectual property rights;

3) Increase the efficiency of the judicial protection of those rights;

4) Russia's international obligations related to the entrance of Russia in the WTO.

The Court for intellectual property rights is into arbitration courts system now. But, unfortunately, in Russia such court does not have any special procedure for the IP disputes settlement and that is why it must use the procedures provided under the Arbitration Procedure Code of the Russian Federation. This court is a specialized arbitration court considering within its competence cases of disputes related to the protection of intellectual property rights, as a court of first and appeal instances. The arbitration courts in Russia form a separate sub-system within the Russian court system and have their own competence and consideration to their powers governed the proceedings rules provided under the Arbitrazh Procedure Code of the Russian Federation. 
At the time of the foundation of the new judicial institution in the system of Russian Court, the authorities of the Russian Federation have viewed a problem related to the competence of the Judge specialized on the IP disputes. The characteristics of intellectual property are such that there are some requirements to the judge not only in the legal field, but also in the technical and sometimes scientific sphere. In addition, changes in legislation provided for participation in the examination of cases by courts, as well as the direction of the Court for intellectual property rights inquiries to persons with special knowledge's. Therefore, the formation of a professional judiciary establishment, which is capable of competently deal with cases of protection of intellectual property rights, as well as the expansion of the forms of special knowledge's in the category of IP cases, is one from the most important components of the effective IP rights judicial protection.

\section{Conclusions}

The inevitability of the transition to an innovative model of economic growth is obvious. Sustainable development must be ensured through the implementation of high-impact projects and priority programs for the development of high-tech sectors of the economy. In summary, we note that the most important condition for the formation of an innovative model of economic development in the Customs Union countries is to create a mature intellectual property market.

With the growth of the role of information in the life of the modern society, the role and status of intellectual property as an object of civil relations not only in Russia but also worldwide has also increased. We cannot argue with the fact that with the development of institution of intellectual property, in particular the institute for industrial property, there is a huge amount of disputes related to it. This entails the improvement and strengthening of legislation in the field of intellectual property protection, including the sphere of defence industry, both at national and transnational level.

The concept of cross-border disputes in the field of intellectual property was proposed with the development of cross-border business relationships, international trade appears. In particular in the area of copyright protection should understand the disputes between the entities of the two different jurisdictions in the field of copyright will normally be resolved by a national court or institution of international commercial arbitration in accordance with the international norms of law and $\backslash$ or with the use of national legislation.

In the Russian Federation, the fantastic work has been done in relation to the improving of the legal framework for the protection of intellectual property, including in the sphere of military-industrial complex. In addition, the international community is well aware the necessity to find a possible solution of the problem of potentially massive global piracy. According to the authors opinion, this decision is necessary to establish international patents registration systems. In this field, the Russian Federation has achieved major successes by participating in international systems of registration of patents, as the PCT and the Madrid System. In addition, between the Russian Federation and a number of countries signed bilateral agreements allowing the patent attorney of one State to conduct business directly with the patent office of another state, in this case representing only the interests of the residents. Residents also have the right to deal directly with the patent office of another state. All abovementioned measures will certainly make it easier to protect the rights of industrial property owners, both in Russia and abroad. 
This publication has been prepared with the support of the "RUDN University Program 5-100."

\section{References}

1. ConsultantPlus, The Civil Code of Russian Federation (Part Four) of 18.12.2006 N 230-FZ (ed. in 07.03.2016) (2018)

2. The Hague Agreement Concerning the International Deposit of Industrial Designs on 6.11.1925 (http://www.wipo.int/wipolex/en/details.jsp?id=12526)

3. The Lisbon Agreement for the Protection of Appellations of Origin and their International Registration of October 31, 1958, as revised at Stockholm on July 14, 1967, and as amended on September 28, 1979 (http://www.wipo.int/lisbon/en/legal_texts/lisbon_agreement.html)

4. The Madrid Agreement Concerning the International Registration of Marks of 14.4.1891 and its Protocol dated 06.28.1989 (Moscow, 2018)

5. P. B. Maggs, A. P. Sergeev, Intellectual property (Moscow, 2000)

6. A. D. Korchagin, The Intellectual Property, 1 (2008)

7. O. L. Kurochkina. Journal of the Property Relations of the Russian Federation, 3, 138 (2013)

8. Paris Convention for the Protection of Industrial Property of March 20, 1883 (with amendments) (http://www.wipo.int/treaties/en/text.jsp?file_id=288514)

9. Patent Cooperation Treaty reached at Washington, DC on June 19, 1970 (with amendments) (http://www.wipo.int/pct/en/texts/articles/atoc.html)

10. Presentation of the Centre for Arbitration and WIPO (http://www.wipo.int/freepublications/ru/arbitration/779/wipo_pub_779.pdf)

11. D. Smith G, Action against small arms and light weapons (Oxfam GB, London, 2003)

12. The 1994 TRIPS Agreement (TRIPS Agreement) (https://www.wto.org)

13. HumanRights, The Russian small arms and light weapons: the problem of unlicensed production abroad (http://www.pircenter.org/kosdata/page_doc/p1482_1.pdf, 2007)

14. WIPO Arbitration and Mediation Center Caseload Summary (www.wipo.int/amc/en/center/caseload.html.http://www.pircenter.org/kosdata/page_d oc/p1482_1.pdf) 